\title{
Be The First To Arrive And The Last To Leave Your Class
}

\author{
Joseph E. Finck, Central Michigan University, USA
}

\begin{abstract}
The time before and after a large class can be very valuable in setting the atmosphere in the room, engaging students, holding impromptu office hours and organizing the material.
\end{abstract}

Keywords: Classroom Management; Engaging Students; Teaching Large Lectures

\section{INTRODUCTION}

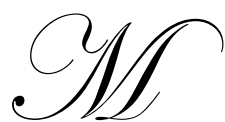

any books and articles on teaching strategies and techniques, as well as manuals prepared by college teaching and faculty development support groups, stress the importance of being organized, engaging the students, and faculty making themselves available to their students (e.g., refs 1-9). This paper discusses how being the first to arrive and the last to leave helps address all these issues and more.

Arriving early for class is natural for some subjects. In science lab courses it is necessary to have all the equipment out, up and running before the students arrive. In science lectures demonstrations frequently need to be set up and checked to make sure they are working. In business classes with students using computers it is wise to make sure all machines are booted and the proper software is loaded. Faculty teaching these classes have learned from experience the disruption caused and time wasted when the equipment is not ready for instruction.

No matter what subject is being taught, it is important to arrive early when teaching a large lecture. Jungic, Kent and Menz point out that, as in a performance, technical difficulties can be problematic in teaching a large lecture. Crackling microphones, bad felt pens, unavailable internet connections, or malfunctioning projectors can cause major disruptions during the lecture. Not only that, but the instructor can quickly loose student attention and respect through a technological break down (ref. 7). It is best to recognize these risks, to plan ahead, and to arrive early to test all devices.

Ideally, all this preparation will be setup with time to spare. Instructors may then use this opportunity to review their notes. However, there are other valuable practices faculty may choose. This paper describes some strategies before and after class that may enhance the classroom atmosphere and the faculty's connection to the students.

\section{PREPARING THE STUDENTS BEFORE THE START OF THE SEMESTER}

With all teaching practices it is good for faculty to plan well ahead and prepare the students as soon as possible. Sometimes the planning can begin at the end of the previous semester. In the last week of the semester in all my classes, I distribute the student opinion surveys and ask the students to give advice to the incoming class. (This practice is extensively discussed in refs. 10 and 11 and briefly described in Section V.) As shown in Table 1, previous students encourage the upcoming class to make use of the professor's availability. The comments made by these experienced students are distributed via Blackboard ${ }^{\mathrm{TM}}$ to the new class a couple of weeks in advance of the start of the new course. So before the semester starts, the new students know that previous students found the professor accessible and interacting with him was valuable and not intimidating. 
At Central Michigan University class lists are available on Blackboard ${ }^{\mathrm{TM}}$ well before the start of the semester. In addition to allowing me to send them the advice from past students, I have the opportunity to reinforce their suggestions. I can also send them the syllabus and the first homework assignment. This lets the class know my expectations for them. I find that most students will start at least part of the homework before the first class meeting, they will get excited about the class ahead, and appreciate the advance organization of the course, including, especially, the dates of all exams.

Blackboard ${ }^{\mathrm{TM}}$ also allows an instructor to print out a photo roster of the students enrolled. Learning the names of the students in your class is one of the best ways to connect with them (see e.g., refs. 2, 12 and 13). And while pictures of the students may not help your remember their names if the class enrollment is over fifty, students will notice and appreciate the effort and the photos will be very useful when giving exams.

The instructor should send an additional e-mail to the students letting them know that he/she will always try to arrive early and leave late every class period. This message may go on to encourage the students to use these opportunities to ask any questions, deal with any problems, or simply chat about anything that interests them. Finally, a similar inviting statement showing the teacher's interest in and accessibility to students should be included in the syllabus.

\section{THE FIRST DAY}

While going over the syllabus on the first day, the instructor typically talks about how to contact her/him and office hours. This is another opportunity for the professor to let the students know your availability before and after class. This should be done with an attitude that convinces the students that you want them to learn and understand the course material, and that you encourage them to meet with you when possible.

On this day, or even in advance, it is important to meet with the faculty members who teach in the class room right before and after you. Let them know that you will always try to arrive early and stay late, but you will do your best to not interfere with them. Your goal is to make a smooth transition from their hour to yours. Share information about what audio-visual equipment you both will use and what should be left on or turned off.

It is also useful to exchange syllabi with the instructors who bracket your time in the classroom. Particular attention should be paid to when you and they are giving exams. You should plan on later having a discussion on how best to handle the days when you and they have exams. Instructors always want to arrive early on these days so they can promptly distribute the exams. And they should also be prepared to stay late to collect them. Exam day behavior of students makes an orderly movement in and out of the room a challenge. Most students want to arrive early when there is a test. They like to get their favorite seat, have their pencils sharpened, and make sure their coffee is safe and accessible. At the end of the exam period there will frequently be students who are reluctant to hand in their work. Getting them to finish may require stern diplomacy. Good classroom management is imperative on exam days. Your goal is to minimize the disruption

\section{ARRIVING BEFORE CLASS STARTS}

Instructors should first check all the equipment. Is the microphone working? Is there chalk or are the dry erase markers good? Is the internet connected? Is the projector working? Once satisfied that all the equipment is functioning well, the professor should display some material that the students see when they take their seats. One strategy is to put up an outline of the material the instructor expects to cover on that day. It is also a chance to put up announcements and remind the students of upcoming homework deadlines or exams.

This is also the opportunity to set the atmosphere in the class. Campus events, current news or sports articles, even if they are not related to the class, could be put on the screen and may interest students. One could even bring culture into the classroom. Juan Peralta from Central Michigan University shows an outline of the day's material along with a picture of a famous piece of art (ref. 14). 
As you are setting up the class, it is an ideal time to throw in a cd so that the incoming students are greeted with music. The practice of playing music before physics class is extensively discussed in refs. 15 and 16 and briefly described in Section VI.) Today's university classrooms, especially lecture halls, are typically mediated. One may find a rack of audio and video equipment or a built in desktop computer. Both systems are capable of playing a cd or dvd and the audio quality is usually quite good. Even if a classroom is not mediated, computers on carts or laptops with cd/dvd players are common. As a result, it is easy for an instructor to slide in a cd and quickly select a track to start a music selection. Before the start of my physics classes, I select a cd which contains a song that can related to the topic of that day or an event—current or historical—of that date. The music is played up to the start of the class and an attempt is made to always end with the "song of the day."

With the classroom prepared, instructors now have a few minutes available. I find that students who never come to office hours will take this opportunity to ask that one quick question about the previous lecture or a problem they are having with homework. This is also when they will talk to you about an upcoming conflict (e.g., doctor's appointment, court date, conference, sister's wedding) that will cause them to miss class. Often they want to know will be covered and how they can best makeup the material they will be missing. Other students will ask to set up an appointment with you because your office hours conflict with their schedule. Many issues can be handled very quickly. For problems requiring more time, arrangements can be made to meet with the student later.

After class students will come to you with similar concerns. One difference is that you will get questions about material that you have just covered. The subject is fresh on their minds and a quick discussion with them is all that is needed to remove their confusion. Most importantly, while talking with the students after class you may discover a mistake you made in lecture or you may realize that you completely confused the entire class. If it is an easily corrected problem, you have the opportunity to return to your office right away and send them an E-mail. If the issue is more complicated, you can prepare to address it at the start of the next class meeting.

What do you do if you have ten minutes before class starts, everything is ready, and no students come to you with questions? It is a great time to interact with them. Connecting and engaging with your students creates an atmosphere that is happy and relaxed and builds a willingness on their part to participate in class (refs. 2, 12, 17, 18). You can talk about current news or the game last night. You can find out what they like and let them find out what you like.

One easy icebreaking technique with students begins by observing their apparel. What they wear gives you an insight into what interests them and allows you to start a conversation. They may have sweatpants with the logo of a team that you also support, or, better yet, your bitter rivals. They may have a shirt from a national park that you have also visited. You may be able to discern from what they are wearing that, like you, they are avid runners or bicyclists. Their clothing may make a political statement which could initiate a conversation. Many students wear clothing that promotes the tour of a rock group leading into a discussion about music. Other students will have sweatshirts that promote student organizations from academic clubs to greek life and you will find that they are proud to tell you about them.

New gadgets, especially phone, computers, tablets and their accessories, intrigue students. They like to show off what they have and they like to see what others are using. It is also likely that they know more about this technology than their teachers do. It can be quite a boost to their confidence if they can advise faculty on new phone applications, or help their professors comparison shop for a new laptop or tablet.

If a faculty member is a pet owner, he/she should mention this or even show a picture of the animal. Many students leave their family pet at home when they come to college. Their pet is important to them and they rank their attachment to their dog higher than to their father (ref. 19). You will find that it is more likely that your students have a picture or their pet than their boy/girlfriend in their phone. Even if the faculty member does not have a pet, bringing up animals is an easy segue to get the student sharing pictures and stories. 


\section{ADVICE FROM PREVIOUS STUDENTS}

Before class begins students will look at RateMyProfessor.com ${ }^{\mathrm{TM}}$ and talk to peers who have taken the class or professor, and wonder if the advice can be trusted. On the first day of class the professor will distribute the syllabus, answer questions about the class, encourage them to work hard, and wonder if the students are paying attention to anything he or she is saying. It is clearly be valuable for students to receive advice from many peers who have taken this class from this professor, and to have this information available before the first day of class.

The students who have taken a class for one or two semesters from a professor can offer valuable suggestions to subsequent classmates. Further, utilizing classroom management tools such as BlackBoard.com ${ }^{\mathrm{TM}}$, it is easy for the professor to pass this advice to his incoming class. Unlike university administered student evaluations of their teachers, the audience described in this study is future students. In addition, since the sample size is large and the student's comments are directed to the same subsequent class, the advice is much more reliable than what is available on websites such as RateMyProfessor.com.

Table 1 displays a summary of the most frequent comments made by the students over three years. One must be impressed with these students. The most common advice they give is exactly what their professor would tell incoming students: do the homework and do it in advance of the deadlines; go to class every day; take advantage of the sample exams provided; find study "buddies"; and make use of the professor's office hours.

Table 1: Summary Of The Most Common Pieces Of Advice Given By Students To Their Incoming Peers

\begin{tabular}{|l|c|c|c|c|}
\hline \multicolumn{1}{|c|}{ Advice } & $\mathbf{2 0 0 4} \mathbf{( N = 6 8 )}$ & $\mathbf{2 0 0 5}(\mathbf{N}=\mathbf{6 7})$ & $\mathbf{2 0 0 6}(\mathbf{N}=\mathbf{5 6})$ & Total $(\mathbf{N}=\mathbf{1 9 1})$ \\
\hline Do all of the homework & 20 & 31 & 38 & 89 \\
\hline Do not procrastinate with homework & 27 & 30 & 25 & 82 \\
\hline Go to class every day & 17 & 34 & 26 & 77 \\
\hline Do practice/sample exams & 20 & 28 & 27 & 75 \\
\hline Make a study friend(s) & 18 & 13 & 5 & 36 \\
\hline Go to office hours & 7 & 10 & 3 & 27 \\
\hline Ask questions; ask for help (general) & 5 & 8 & 3 & 16 \\
\hline
\end{tabular}

\section{MUSIC BEFORE THE START OF CLASS}

The times before and after class are valuable instructional periods and it is a good practice for faculty to arrive before the start of class and remain until all the students have left. These are good opportunities to resolve those "I just have one quick question" issues. In introductory physics courses, faculty typically arrive early to set up demonstrations This is an ideal time to throw in a cd so that the incoming students are greeted with music. While the curriculum of a physics class is an ideal match for many musical pieces, classes in any college discipline could successfully use music before class to enliven the students and introduce material.

Generally, it is quite easy to pick a "song of the day" for physics class, because the topics naturally match so many songs. This is particularly true for heat, light, astronomy (moon, sun, and planets), the motion of, and forces on, moving objects (trains, planes, and automobiles). There are also compact discs ("albums") with physics topics in the title ("The Planets" by Gustav Holtz) or in the name of the performing group (The Electric Light Orchestra). Other disciplines, such as history, also offer many choices for music. A course in western civilization could play music that was composed during the historical period discussed for that day; and a wealth of material is available for a course about Vietnam.

Sometimes there are physics topics for which we have not found many songs that connect to the curriculum. This is particularly true when atomic and quantum physics are covered. In addition, there are occasions in the academic and Julian calendars and daily events that occur (hurricanes, team victories or losses, elections) and that trump the physics topic of the day. For example, on the last day to withdraw from class, "With You or without You" by U2 is played. Similarly, on both November 22 and January 15, "Abraham, Martin, and John" is always the song of the day. And on the first day of spring, "Appalachian Spring" by Aaron Copland greets the students as they 
arrive. In addition, one can always celebrate the anniversary of the birth or death of Elvis, Mozart, Miles Davis, Patsy Cline, or John Lennon. The students seem to appreciate this variety and since they are typically isolated college students, their physics class can become a source for current events and historical perspectives.

There are times when students need a little history lesson to appreciate the song of the day. Two good examples of this are "Back in the USSR" by the Beatles, which is played on the anniversary of Sputnik's launch and "Volunteers [for America]," which is used to empathize the significance of the G.I. Bill. In addition, there are times when the music connection is more obtuse such as when the theme song to Star Wars is played on opening day of the baseball season. James Earl Jones was the voice of Darth Vader in Star Wars. He also played important roles in Field of Dreams and The Sandlot-two popular baseball movies. We have observed that students enjoy and are challenged by these convoluted connections.

With the music playing before class it is quite rare to find students trying to catch a nap, or read the newspaper, or listen to their ipods TM. Students are often observed singing and even sometimes dancing together. The music may give them something to talk about when they discover that they have similar musical tastes. In addition, the students often wonder or ask how the song will relate to the curriculum. They even come to class with suggestions for the song of the day.

\section{CONCLUSION}

When faculty are the first to arrive to their classroom they first check to make sure all the audio visual equipment is turned on and functioning. Then they have time to post announcements, put up outlines of class material to be covered, and prepare handouts for distribution. After these classroom management details are addressed, the instructor has the opportunity to meet with students and address their quick concerns. It is also a chance to talk with students and find out more about their interests. At the end of class the instructor should be the last person to leave. It is the perfect time assess the students' understanding of the material just covered and take care of questions they may have. Early in the semester it is important for the faculty member to communicate his availability to the students before and after class. In addition, he/she should communicate with the instructors that bracket his/her course to help with the between periods classroom management. This all helps to create a relaxed atmosphere in the room and builds respect between the professor and students.

\section{AUTHOR INFORMATION}

Joseph E. Finck received his Ph. D. in nuclear physics from Michigan State University in 1982. He is currently a Professor of Physics at Central Michigan University. He has over forty publications in experimental nuclear physics and an additional ten publications on teaching strategies and techniques. E-mail: Finck@ phy.cmich.edu

\section{REFERENCES}

1. Chickering, A.W., \& Gamson, Z.F. (1991). Applying the seven principles for good practice in undergraduate education. New Directions for Teaching and Learning, 47. Fall. San Francisco: JosseyBass.

2. Stanley, C.A., \& Porter, M.E. (2002). Engaging large classes: Strategies and techniques for college faculty. Bolton, MA: Anchor.

3. Carbone, E. (Ed.). (1998). Teaching large classes: Tools and strategies. Thousand Oaks, CA: Sage Publications.

4. Casado, M. (2000). Teaching methods in higher education: A student perspective. Journal of Hospitality \& Tourism Education, 12, 65-70.

5. Toth, L., \& Montagna, L. (2002). Class size and achievement in higher education: A summary of current research. College Student Journal, 36(2), 253-261.

6. McLeod, N. (1998). What teachers cannot do in large classes (Research Rep. No. 7). Leeds, UK: Leeds University. 
7. Jungic, V., Kent, D., and Menz, P. (2006). Teaching Large Math Classes: Three Instructors, One Experience. International Electronic Journal of Mathematics Education, 1(1), 1-15. http://www.iejme.com, 2006

8. Ives, S. M., (2000). Survival handbook for teaching large classes. UNC Charlotte Faculty Center for Teaching http://teaching.uncc.edu/resources/best-practice-articles/large-classes/handbook-large-classes.

9. Bruff, D. (2010). Lecturing. Vanderbilt University Center for Teaching. http://cft.vanderbilt.edu/teachingguides/teaching-activities/lecturing/

10. DeLine, A. D. and Finck, J. E. (2008). Students Giving Students Advice Before the First Day. Journal of College Teaching \& Learning 4, 29-39.

11. DeLine, A. D. and Finck, J. E. (2008). Do Students Listen to Advice from Their Experienced Peers? Journal of College Teaching \& Learning 4, 19-26.

12. Zakrajsek, Z. (2007). Effective teaching when class size grows. Observer: Association for Psychological Science.

13. Bradley, C., and Green, E. (2011). Teaching effectively in large classes. University of Regina Centre for Teaching and Learning. http://www.uregina.ca/ctl/blog/teaching-effectively-in-large-classes

14. Petalta, J. (2011). Personal communication. Central Michigan University.

15. White, D. R. and Finck, J. E. (2006). Physics Rocks in the Ten Minutes before Class. Proceedings of the 2006 College Teaching \& Learning Conference, Disney World, Florida.

16. White, D. R. and Finck, J. E. (2006). Get in Rhythm before Class.” Journal of College Teaching \& Learning, 3, 41-50.

17. UNESCO (2006). Practical tips for teaching a large classes: a teacher's guide. UNESCO Bangkok: Asia and Pacific Regional Bureau for Education

18. Waugh, G. H. and Waugh, R. F. (1999). The value of lectures in teacher education: the group perspective. Australian Journal of Teacher Education. 24, 35-51.

19. Kurdek, L. (2008.) Pet dogs as attachment figures. Journal of Social and Personal Relationships. 25 , 247-266. 